\title{
GROWTH AND PHENOLOGY OF ESTABLISHED TILIA CORDATA STREET TREES IN RESPONSE TO DIFFERENT IRRIGATION REGIMES
}

\author{
Oliver Bühler, Christian Nørgård Nielsen, and Palle Kristoffersen
}

\begin{abstract}
The effect of different irrigation regimes on growth and phenology of 100 established Tilia cordata street trees was investigated during the growth period of 2004. Relative stem increment increased significantly when irrigating with 280,320 , or $640 \mathrm{~L}(74,84.5$, and $169 \mathrm{gal})$ of water throughout the growth period. The length of the growth period was affected by irrigation regimes in regard to termination of growth, as the trees receiving 640 L (169 gal) had a growth period significantly longer than the control trees. These results indicate that growth and growth period of street trees are augmented by an increase in the amount of water available to them. In addition, block effects concerning the start of the growth period were observed, as trees situated on the northern side of the street initiated stem growth 7 days earlier than the trees on the southern side.
\end{abstract}

Key Words. Irrigation; phenology; stem growth; street trees; Tilia cordata; tree management; urban climate; water balance.

Inadequate supply of water is considered to be a critical factor concerning establishment and vitality of street trees (Hampel 1893; Gilbertson and Bradshaw 1985; Clark and Kjelgren 1990; Balder et al. 1997; Sæbø et al. 2003). Water deficiencies on urban sites may occur because of lack of precipitation, a limited soil water reservoir due to restricted infiltration of precipitation, limited soil volumes, or inappropriate soil characteristics - in particular, due to soil compaction (Impens 1999). At the same time, temperature in urban areas is generally higher and relative humidity is lower, increasing the atmospheric demand (Whitlow et al. 1992; Kjelgren and Clark 1993).

These specific urban site conditions may, separately or in combination, result in water deficiencies eventually expressed as a depression of growth and vitality (Montague et al. 2000) or even increased mortality, particularly in the case of recently planted street trees (Gilbertson and Bradshaw 1990).

So far, irrigation is generally restricted to the first years of newly planted trees. Previous studies report somewhat inconsistent results of additional irrigation. Whereas some provide evidence of growth responses to an additional supply of water (Bellet-Travers and Ireland 1999), others find no significant growth effects (Whitlow et al. 1992; Costello et al. 2005). Many irrigation studies, however, were carried out in field plots and may therefore not necessarily reflect the special situation of a street tree. In a European survey, Pauleit et al. (2002) report that drought is recognized as a problem for establishment and maintenance of urban trees but found that it is difficult to quantify the extent of the problem.

The present study investigated the irrigation responses of a widely used street tree species (Tilia cordata [littleleaf linden]) and was carried out on an existing street plantation consisting of 100 trees.

Its main purpose was to assess whether irrigation of wellestablished street trees yields additional, measurable growth responses and, thus, whether lack of water is a growth reducing factor. Furthermore, effects of irrigation on phenological parameters were investigated.

\section{MATERIALS AND METHODS Test Plants and Test Sites}

The experiments were conducted in 2004 on a plantation of 100 Tilia cordata 'Greenspire' and T. cordata 'Erecta' situated on both sides of Frederikssundsvej in Copenhagen, Denmark. Frederikssundsvej is an arterial road leading from east to west, surrounded by a variety of building structures. The trees were planted in 1996-97 and are today of uniform appearance; average stem circumference at a height of $1 \mathrm{~m}$ (3.3 ft) is $358 \mathrm{~mm}$ (14.1 in) (S.D. $\pm 48 \mathrm{~mm}$ [1.89 in]).

The planting pits comprise a surface area of $6.4 \mathrm{~m}^{2}(68.9$ $\mathrm{ft}^{2}$ ) and are surrounded by elevated curbstones founded in a concrete base reaching to a depth of $50 \mathrm{~cm}(1.6 \mathrm{ft})$. The surface of the pit is covered with a layer of coarse bark mulch. To a depth of $60 \mathrm{~cm}(2 \mathrm{ft})$, the pit is filled with an artificial tree planting substrate of sandy texture with little silt and no clay. Humus content is low, too, except for the very top layer where bark mulch is decomposed. Beyond a depth of $60 \mathrm{~cm}(2 \mathrm{ft})$, the soil consists of loamy clay.

Excavations revealed that main root growth is restricted to the upper $60 \mathrm{~cm}(2 \mathrm{ft})$, with extensive fine root growth just below the bark mulch layer. Very few roots have been observed to grow under the curbstones into adjacent areas, and virtually no root growth was observed deeper than 60 $\mathrm{cm}(2 \mathrm{ft})$. No technical applications for improved drainage or aeration had been installed on the test site.

An additional 20 Tilia spp. park trees situated in a nearby park were incorporated in the test as nontreated reference trees. The park trees were approximately the same age; 
average stem circumference at $1 \mathrm{~m}(3.3 \mathrm{ft})$, however, was $499 \mathrm{~mm}$ (19.6 in) (S.D. $\pm 54 \mathrm{~mm}$ [2.1 in]). The soil between the park trees was covered with herbaceous vegetation.

\section{Irrigation}

The street trees were treated with 5 different irrigation regimes including a control receiving no irrigation. Both the total amount of water supplied $(640,320$, or 280 L [169, 84.5, or 74 gal], 140 L [37 gal], no irrigation) and the irrigation frequency varied (Table 1). Water was supplied manually with a water hose equipped with a sprayer and a water meter. We attempted to spread the water evenly over the whole surface of the planting pit. Curbstones surrounding the planting pit prevented runoff.

\section{Growth Response}

Stem circumference was measured weekly at a stem height of $1 \mathrm{~m}(3.3 \mathrm{ft})$ in the period from 5 April until 30 September using a measuring tape. From these measurements, stem cross-sectional area, absolute stem area increment, relative stem area increment, and annual ring width were calculated.

\section{Statistics and Data Analysis}

The 5 treatments (Table 1) were assigned to the 100 street trees according to a completely randomized block design consisting of 4 blocks with 25 trees each. Thus, each block contained 5 replicates of each treatment, amounting to 20 replicates altogether. Two of those blocks were situated on the northern side of the street, and the other two blocks on the southern side.

Based on the stem circumference measurements, stem cross-sectional area (CSA) values were calculated on tree level for each assessment time. For each tree, CSA at the first and at the last assessment time of the year was used to calculate the total CSA increment during the entire growing season of 2004. For each of the 22 measurements, the absolute increment was calculated. Finally, the percentage of total yearly CSA increment was calculated for each tree and assessment time. These data illustrate the relative distribution of increment over the growing season, ranging from 0 to $100 \%$. The distribution of these data is S-shaped, and a range of models was tested for their suitability to describe the relative increment curves. The Gompertz growth function (Equation 1) proved to be most suitable for the present data set and was fitted to the stem growth data of every single tree.

$$
I=100 * e^{-e^{\left(-b^{*}(d a y-c)\right)}}
$$

Systematic model errors were found to be similar for all treatments around day 130 and day 270. It was therefore decided to estimate the day for onset and cessation of growth around these to days in order to minimize the influence from model bias on treatment effects. These two days correspond to an average of $4 \%$ and $98 \%$ of the yearly increment, respectively. Thus, the days for onset and cessation of stem diameter growth were estimated for every single tree using Equations 2 and 3 (parameters $b$ and $c$ are from the Gompertz curve fit).

$$
\begin{aligned}
& \text { day of onset }=\frac{c+\ln (\ln (100)-\ln (4))}{-b} \\
& \text { day of cessation }=\frac{c+\ln (\ln (100)-\ln (98))}{-b}
\end{aligned}
$$

Data were analyzed by means of SAS version 8.02 (SAS Institute, Cary, NC) and Microsoft Excel 2000. CSA increment was subjected to an analysis of variance (ANOVA) using the GLM procedure in SAS, including block and treatment effects. The beginning and end of the growing season were determined using the NLIN procedure in SAS.

\begin{tabular}{|c|c|c|c|c|c|c|}
\hline Date & Day of year & $\begin{array}{l}\text { Treatment } 1 \\
\text { (L/tree) }\end{array}$ & $\begin{array}{l}\text { Treatment } 2 \\
\text { (L/tree) }\end{array}$ & $\begin{array}{l}\text { Treatment } 3 \\
\text { (L/tree) }\end{array}$ & $\begin{array}{l}\text { Treatment } 4 \\
\text { (L/tree) }\end{array}$ & $\begin{array}{l}\text { Sum } \\
\text { (L) }\end{array}$ \\
\hline May 26/27 & $147 / 148$ & 100 & 50 & 50 & 100 & 6,000 \\
\hline June 10 & 162 & 100 & 50 & - & - & 3,000 \\
\hline July 15 & 197 & 80 & 40 & - & - & 2,400 \\
\hline July 26 & 208 & 80 & 40 & 40 & 80 & 4,800 \\
\hline August 2 & 215 & 100 & 50 & - & - & 3,000 \\
\hline August 11 & 224 & 100 & 50 & 50 & 100 & 6,000 \\
\hline August 26 & 239 & 80 & 40 & - & - & 2,400 \\
\hline Whole period & & 640 & 320 & 140 & 280 & 27,600 \\
\hline \multicolumn{7}{|l|}{ Equivalent } \\
\hline precipitation (mm) & & 100 & 50 & 22 & 44 & \\
\hline
\end{tabular}

Table 1. Frequency and time of irrigation and amounts of water distributed during each irrigation. "Equivalent precipitation" denotes the amount of precipitation corresponding to the amount of water applied by irrigation. 
Subsequently, stem increment and growth period means were compared using least significant difference (LSD) comparisons at $P<0.05$. Stem increment means were further separated with a Duncan test.

Relevant climate data were obtained from the Danish Meteorological Institute (DMI 2004).

\section{RESULTS \\ Precipitation}

Precipitation distinctly surpassed the average during the period April to September 2004. Altogether, $320 \mathrm{~mm}$ (12.6 in) (corresponding to 2,048 L [540.9 gal] per planting pit) of precipitation were recorded for the capital area in this period, exceeding the average values of 1961-90 by $55 \mathrm{~mm}$ (2.2 in), corresponding to $352 \mathrm{~L}$ (98 gal) of water per planting pit (DMI 2004). As is valid for the irrigation water, runoff was supposedly minimal due to the elevated curb. However, unknown amounts of precipitation were intercepted by street tree crowns, parking vehicles, and buildings, so the actual amount of water infiltrating the planting pit does not correspond precisely to the recorded precipitation.

\section{Growth Response}

Significantly augmented relative stem area increment was registered after irrigation with 280, 320, and $640 \mathrm{~L}$ (74, 84.5 , and 169 gal) throughout the whole growth period (comparisons of LSD at $P<0.05$ ). The lowest relative stem increment was yielded by the untreated control (10.88\%), and the highest relative stem increment was yielded by the trees receiving most water $(15.14 \%)$. The relative stem area increment of the nontreated park trees surpassed any of the street trees, albeit no significant differences to the street tree treatment irrigated with 640 L (169 gal) of water could be determined (Table 2, Figures 1 and 2).

If separating means with a Duncan test $(P<0.05)$, significantly augmented stem area increment was achieved by the trees receiving most water (640 L [169 gal]).

\section{Phenology}

Because irrigation started well after initiation of stem increment, treatment effects were absent in regard to the onset of growth. However, considerable and significant $(P<0.001)$ block effects were revealed by an ANOVA of the days for growth initiation. Thus, the trees in blocks 1 and 2, positioned on the northern side of the east-westgoing street, started stem growth 7 days earlier than the trees in blocks 3 and 4 (Table 3). These results are supported by cursory observations of budbreak on day 118 (April 27), when 96\% of the trees in blocks 1 and 2 had flushed, while this was the case for only $41 \%$ of the trees situated in blocks 3 and 4.

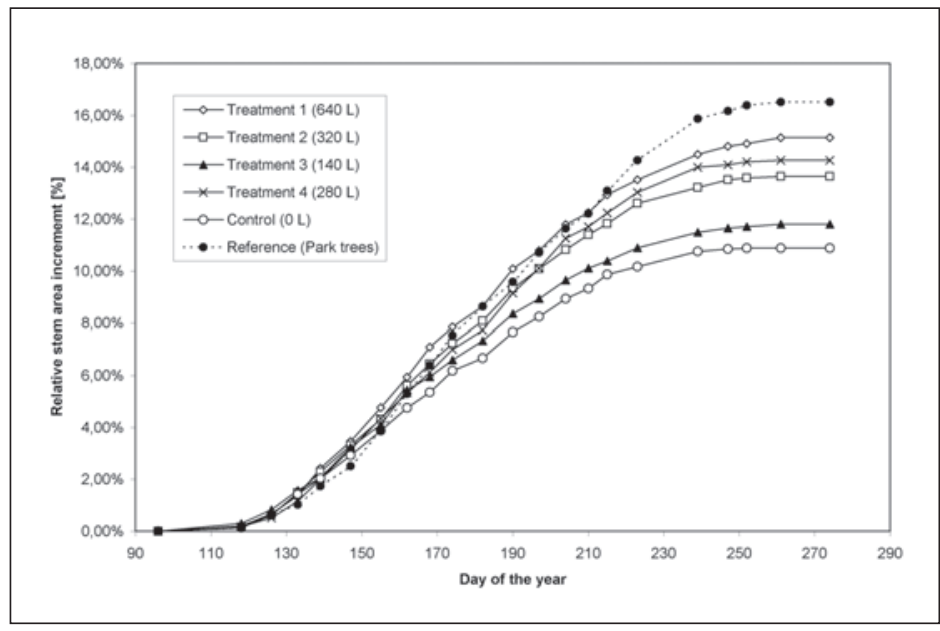

Figure 1. Growth curves for all treatments and reference trees (park trees), illustrating relative stem area increment at 1 m stem height. Each point denotes the mean value of 20 replicates.

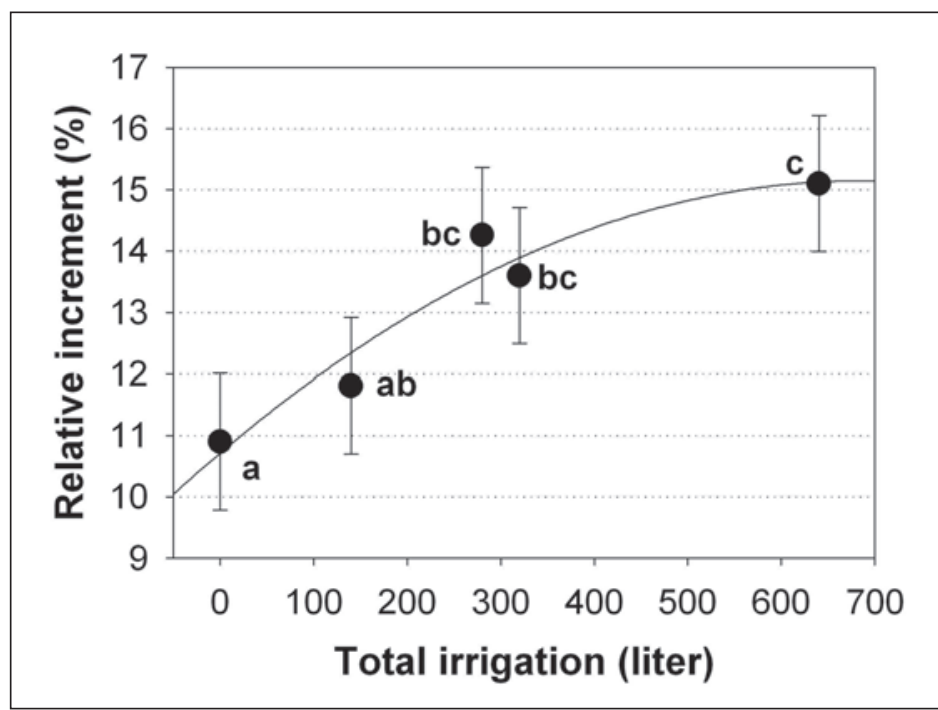

Figure 2. Relative stem area increment in response to total irrigation over the whole growth period. Error bars denote prediction errors; different letters denote significant differences between means $(P<0.05)$. 
Table 3. Block effects on initiation of stem growth. Blocks 1 and 2 are situated on the northern side of Frederikssundsvej; blocks 3 and 4 are situated on the southern side.

\begin{tabular}{ll}
\hline Block & Start of stem growth (day of year) \\
\hline 1 & 121 (30 April) a* \\
2 & 121 (30 April) a \\
3 & 128 (7 May) b \\
4 & 128 (7 May) b \\
Park trees & 131 (10 May) b \\
\hline
\end{tabular}

*Values in columns differ significantly when followed by different letters (according to LSD test, $P<0.05$ ).

Irrigation treatments resulted in a significantly delayed cessation of stem growth and, thus, ultimately in a prolonged growth period.

In terms of the entire growth period, irrigation with 640 L (169 gal) resulted in a growth period prolonged by 17 days compared to the control trees (significant for $P<0.05$ ). Irrigation with less than 640 L (169 gal) did not yield any significant prolongation of the growth period. The park trees had the longest growth period: they grew 20 days longer compared to the control street trees (Figure 3).

Visual assessment of leaf senescence, however, revealed no differences between the street trees, but leaf coloring of the park trees was observed to be delayed by 7 to 14 days.

The time of cessation of growth was to some extent correlated to the total stem area increment $\left(R^{2}=0.7\right)$ (Figure 4).

\section{DISCUSSION}

Although uniform in appearance, the investigated street trees are presumably subjected to very heterogenic influences regarding soil condition (structure, fertility) and

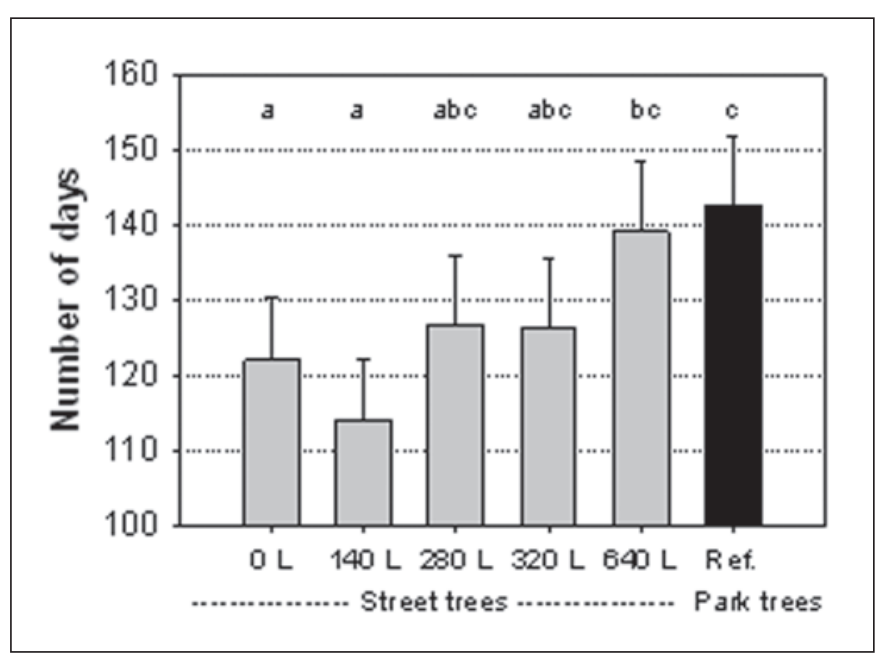

Figure 3. Duration of the growth period. Error bars denote prediction errors; different letters denote significant differences between means $(P<0.05)$. climatic conditions (shading by buildings). This is reflected by a high variation of the stem area increment, as opposed to that of the park trees incorporated in these investigations. Whereas the standard deviation of the total relative increment ranges from $\pm 5.01 \%$ to $\pm 6.29 \%$ for the street trees, it amounts to $\pm 2.61 \%$ for the park trees. As to the climatic heterogeneity, this is reflected by the diverging times of growth initiation of the street trees on the southern and on the northern side of the street, respectively. The assumption of heterogenic soil conditions is further supported by investigations by Nielsen et al. (2005) of the soil water dynamics on the same site.

Still, a significant growth response to the irrigation treatments was determined when irrigating with 280 L (74 gal) and more, even though precipitation in the test year was unusually high-indicating that water is indeed limiting street tree growth. This extends the conclusions by Whitlow et al. (1992), who, also working with in situ urban trees of the same species, determined no growth response to an irrigation regime of 19 L ( 5 gal) of water weekly during 3 months. According to our results, the quantity of water thus supplied to the trees may still be below the response threshold. Furthermore, it may also be of significance that the study by Whitlow et al. (1992) investigated irrigation responses of only 5 individuals, possibly too small a number to overcome the variability met in the urban landscape.

Growth responses of woody ornamentals to irrigation have been reported by Devitt et al. (1994) on Quercus virginiana and Bellet-Travers and Ireland (1999) on Platanus $\times$ hispanica, but contradicting results have been published, too. Costello et al. (2005), for example, found no additional growth of different Quercus species after a program of 4 years of irrigation, irrigating with respective averages of

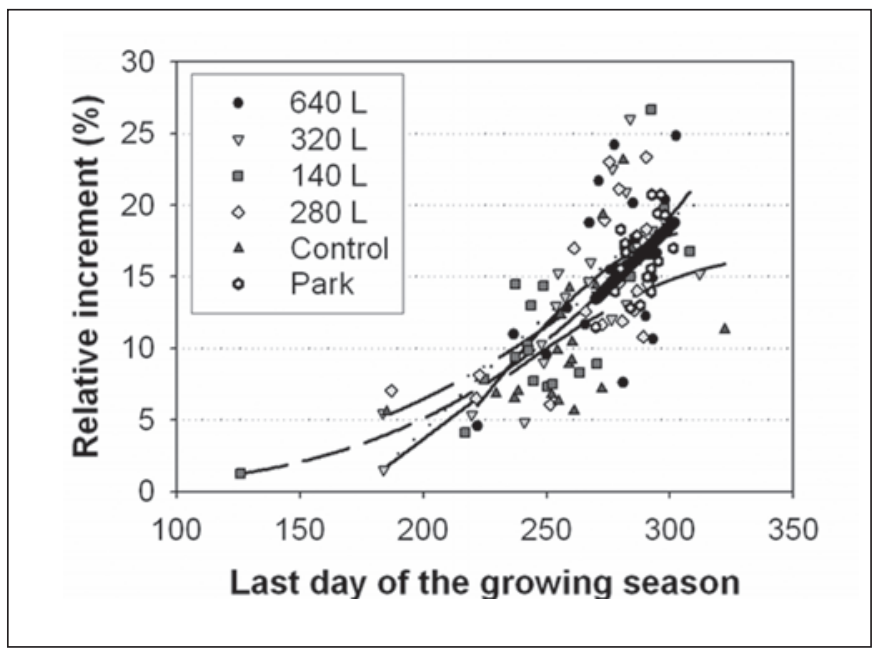

Figure 4. Correlation between the last day of the growth period and relative stem increment. Overall $R^{2}=0.7$. 
13.3 L (3.5 gal) and 26.6 L (7 gal) weekly. However, because the cited studies were conducted on field plots, the same species may have reacted differently if situated under street tree conditions.

Presumably, a year with less precipitation would have widened the gap between irrigated and non irrigated trees further, as well as widening the gap between the park trees and the street trees in general. As it was, the nonirrigated control street trees grew less than some of the irrigated trees and the park trees, but a relative stem area increment of $10.88 \%$, corresponding to an annual ring of $3 \mathrm{~mm}(0.12$ in), appears to be quite acceptable growth.

Irrigation, however, should not be considered as the only way of providing additional amounts of water to street trees. In 2004, for instance, an increase of the surface of the planting pit by $2 \mathrm{~m}^{2}\left(21.5 \mathrm{ft}^{2}\right)$ would have allowed approximately $640 \mathrm{~L}$ (169 gal) of additional precipitation to enter the planting pit, corresponding to the amount presented by the highest irrigation treatment. For further discussion of management options, see, for example, Nielsen et al. (2005).

In addition to limiting stem increment, water deficiencies also limited the length of the growth period, and between those two parameters a certain correlation has been proven. The reported prolongation of growth periods in urban areas (Zhang et al. 2004) due to a warmer climate can, at least in regard to street trees, not be confirmed because lack of water had the opposite effect.

Interestingly, growth initiation of street trees situated less than $10 \mathrm{~m}(33 \mathrm{ft})$ apart has been shown to vary significantly. This phenomenon is probably explained by the influences of temperature on springtime phenology. The southern side of the test street was subjected to more pronounced shading by buildings, while the northern side received more solar radiation, resulting in higher temperatures of soil and plant tissue. This again resulted in earlier initiation of growth, as shown by analysis of growth models, but, in contrast to the differences regarding cessation of growth, the differences in growth initiation were nevertheless perceivable by visual inspection. The reported earlier growth initiation in urban areas compared to rural areas reported by Kramer (1995), White et al. (2002), and Roetzer et al. (2000), for example, thus proves to be subjected to considerable variations also within urban perimeters.

\section{CONCLUSION}

Although the test was carried out in a year with aboveaverage precipitation during the growth period, irrigation yielded significant results in the form of an increase of relative stem increment and a longer period of stem growth. Those two parameters furthermore were shown to be interdependent to a certain degree. This finding indicates clearly that growth of the tested street trees is suboptimal due to lack of water and can be optimized by management approaches-be it by means of irrigation or other arrangements that improve the water supply during the growth period.

Microclimatic conditions turned out to delay growth initiation for trees situated on the shady side of the street, emphasizing the very heterogeneous site conditions of street trees of otherwise very similar appearance. The heterogenic site conditions are further illustrated by the pronounced spread of the collected data.

\section{LITERATURE CITED}

Balder, H., K. Ehlebracht, and E. Mahler. 1997. Strassenbäume: Planen, Pflanzen, Pflegen am Beispiel Berlin. Patzer Verlag, Berlin, Germany. 240 pp.

Bellet-Travers, D.M., and C.R. Ireland. 1999. A comparison of the growth responses and physiology of two amenity tree species subjected to water Stress. Acta Horticulturae 496:339-345.

Clark, J.R., and R. Kjelgren.1990. Water as a limiting factor in the development of urban trees. Journal of Arboriculture 16:203-208.

Costello, L.R., K.S. Jones, and D.D. McCreary. 2005. Irrigation effects on the growth of newly planted oaks (Quercus spp.). Journal of Arboriculture 31:83-87.

Danish Meteorological Institute (DMI). 2004. Weekly reports on climate in the capital area. Copenhagen, Denmark.

Devitt, D.A., R.L. Morris, and D.S. Neumann. 1994. Evapotranspiration and growth response of three woody ornamental species placed under varying irrigation regimes. Journal of the American Society of Horticultural Science 119:452-457.

Gilbertson, P., and A.D. Bradshaw. 1985. Tree survival in cities: The extent and nature of the problem. Arboricultural Journal 9:131-142

- 1990. The survival of newly planted trees in inner cities. Arboricultural Journal 14:287-309.

Hampel, C. 1893. Stadtbäume-Anleitung zum Pflanzen und Pflegen der Bäume in Städten, Vororten und auf Landstraßen. Verlag von Paul Parey, Berlin, Germany. 73 pp.

Impens, R.A. 1999. Life conditions and stress for urban trees: Example of Brussels city. Acta Horticulturae 496:253-259.

Kjelgren, R.K., and J.R. Clark. 1993. Growth and water relations of Liquidambar styraciflua L. in an urban park and plaza. Trees 7:195-201.

Kramer, K. 1995. Phenotypic plasticity of the phenology of seven European tree species in relation to climatic warming. Plant, Cell, and Environment 18:93-104.

Montague, T., R. Kjelgren, and L. Rupp. 2000. Surface energy balance affects gas exchange and growth of two irrigated landscape tree species in an arid climate. . Journal of the American Society of Horticultural Science 125:299-309. 
Nielsen, C.N., O. Bühler, and P. Kristoffersen. 2005. Soil water dynamic and growth of street and park trees. (Submitted to Journal of Arboriculture.)

Pauleit, S., N. Jones, G. Garcia-Martin, J.L. GarciaValdecantos, L.M. Rivière, L. Vidal-Beaudet, M. Bodson, and T.B. Randrup. 2002. Tree establishment practice in towns and cities-Results from a European survey. Urban Forestry \& Urban Greening 1:83-96.

Roetzer, T., M. Wittenzeller, H. Haeckel, and J. Nekovar. 2000. Phenology in central Europe-Differences in urban and rural areas. International Journal of Biometeorology 44:60-66.

Sæbø, A., T. Bendedikz, and T B. Randrup. 2003. Selection of trees for urban forestry in the Nordic countries. Urban Forestry \& Urban Greening 2:101-114.

White, M.A., R.R. Nemani, P.E. Thornton, and S.W. Running. 2002. Satellite evidence of phenological differences between urbanized and rural areas of the eastern United States deciduous broadleaf forest. Ecosystems 5:260277.

Whitlow, T.H., N.L. Bassuk, and D.L. Reichert. 1992. A 3year study of water relations of urban street trees. Journal of Applied Ecology 29:436-450.

Zhang, X., M.A. Friedl, C.B. Schaaf, A.H. Strahler, and A. Schneider. 2004. The footprint of urban climate on vegetation phenology. Geophysical Research Letters $31: 12209$
Acknowledgments. We thank Jan Bøje, Københavns Kommune, Vej og Park for the funding of the irrigation works; Uffe Andreasen, KommuneTeknik København for technical assistance; and Frank Andersen and colleagues, KommuneTeknik København, for assistance with the irrigation works.

Oliver Bühler (corresponding author)

Research Assistant, M.Sc. Horticulture

Division of Parks and Urban Landscapes

Danish Centre for Forest and Landscape Planning-KVL

Royal Veterinary and Agricultural University

Rolighedsvej 23, DK-1958 Frederiksberg C

Denmark

olb@kvl.dk

Christian Nørgård Nielsen

Prof, dr. agro

Division of Parks and Urban Landscapes

Danish Centre for Forest and Landscape Planning-KVL

Royal Veterinary and Agricultural University

Rolighedsvej 23, DK-1958 Frederiksberg C

Denmark

cnn@kvl.dk

Palle Kristoffersen

Senior advisor, Ph.D.

Division of Parks and Urban Landscapes

Danish Centre for Forest and Landscape Planning-KVL

Royal Veterinary and Agricultural University

Rolighedsvej 23, DK-1958 Frederiksberg C

Denmark

pkr@kvl.dk 
Résumé. Les effets de différents régimes d'irrigation sur la croissance et la phénologie de 100 Tilia cordata implantés le long de rues ont été mesurés durant la période de croissance de 2004. La croissance relative des tiges augmentait significativement lorsque les arbres étaient irrigués avec 280, 320 ou 640 L d'eau durant la période de croissance. La durée de la période de croissance était affectée par le régime d'irrigation en regard de la fin de la croissance; les arbres recevant jusqu'à 640 L d'eau avaient une période de croissance significativement plus longue que les arbres du groupe témoin. Ces résultats indiquent que la croissance et la période de croissance des arbres de rues augmentent avec l'accroissement en apport d'eau disponible pour ces derniers. De plus, des effets géographiques étaient observables selon le positionnement des arbres, ceux situés du côté nord de la rue initiant la croissance de leur tige sept jours plus tôt que ceux situés du côté sud.

Zusammenfassung. Der Effekt von verschiedenen Bewässerungssystemen auf Wachstum und Phänologie von 100 etablierten Winterlinden (Tilia cordata) wurde in der Wachstumsperiode von 2004 untersucht. Der relative Stammumfang stieg deutlich mit der Bewässerung mit 280, 320 oder 6401 Wasser während der Wachstumsperiode. Die Länge der Wachstumsperiode wurde durch die Bewässerung beeinflusst, Bäume mit Wassergaben von 6401 hatten eine längere Wachstumsperiode als die Kontrollbäume. Diese Ergebnisse zeigten, dass Wachstum und Wachstumsdauer beeinflusst werden können durch die steigenden Bewässerungsgaben. Zusätzlich wurden Standorteinflüsse beobachtet, da Bäume auf der Nordseite der Strasse 7 Tage früher zu wachsen begannen als die Bäume auf der Südseite.

Resumen. Se investigó el efecto de diferentes regímenes de riego en el crecimiento y fenología de 100 árboles de Tilia cordata en la calle durante el periodo de crecimiento de 2004. El incremento relativo del tallo aumentó significativamente cuando se regó con 280 L, 320 L o 640 L (74 gal, 84,5 gal y 169 gal, respectivamente) de agua a lo largo del periodo de crecimiento. La duración del periodo de crecimiento, respecto a la terminación del mismo, fue afectada por los regímenes de riego, ya que los árboles que recibieron 640 L (169 gal) tuvieron un periodo de crecimiento significativamente más largo que los árboles de control. Estos resultados indican que el crecimiento y el periodo de crecimiento de los árboles de la calle aumentaron al aumentar la cantidad de agua disponible para ellos. Adicionalmente, se observó que el comienzo del periodo de crecimiento fue afectado por la situación geográfica, ya que los árboles situados en el lado norte de la calle iniciaron el crecimiento del tallo 7 días antes que los árboles en el lado sur. 